\title{
EFFECT OF INTERACTION BETWEEN SEASON AND ARAK (Salvadora persica) SUPLEMENTATION ON RABBITS: 1- PRODUCTIVE AND SOME PHYSIOLOGICAL PERFORMANCE OF GROWING RABBITS.
}

El-Sawy, M. A.; Kh. A. A. Ali; M. N. F. Hassanein and K.H. El-Kholy Department of Rabbit, Turkey and Water Fowl Breeding Research, Animal Production Research Institute, Agricultural Research Centre, Dokki, Giza, Egypt.

\begin{abstract}
Ninety-six weaned New Zealand White (NZW) rabbits, aged 30 day and weighing average $586 \pm 13.23 \mathrm{~g}$ were used in this study during winter and summer seasons. In each season, two groups were used; the first group was fed ad libitum a commercial pelleted diet and was kept untreated to serve as a control, while the other group was fed the same diet, but supplemented with $0.2 \%$ dried Arak powder. Daily weight gain, feed intake and some thermo-respiratory responses were recorded from weaning up to 12 week of age. At this time ten rabbits from each group were slaughtered and carcass characteristics were measured and blood samples were collected. Results obtained showed that final body weight at 12 week of growing NZW rabbits increased significantly $(P \leq 0.05)$ with Arak inclusion under winter and summer seasons compared to control group, whereas daily feed intake had insignificant differences as Arak treatment. Dietary supplementation of Arak to NZW rabbits either in winter or summer season caused significant $(P \leq 0.05)$ increased in some haematological and biochemical parameters. Interaction between season and Arak addition effects were significant $(P \leq 0.05$ or $P \leq 0.01)$ on weights of carcass and its components. The lowest values of all thermo-respiratory traits were recorded for rabbits reared during winter season than those in the summer season. Also, results demonstrated that rabbits treated with Arak in the summer season retained rabbit's respiration rate and rectal and skin temperatures to nearly that of the untreated group in the winter season. The present results indicate an improvement in net profit, by about $20 \%$, for rabbits fed diet containing Arak compared to those fed diet with no addition.
\end{abstract}

Keywords: Rabbits, Arak, growth performance, carcass traits, thermo-respiratory. .

\section{INTRODUCTION}

The climate and nutrition factors are so important, which affect the economic intensive rabbit's production, under Egyptian conditions Marai et al. (2008).

In Egypt, the breeding season of rabbits is normally from October till April, due to the negative effects of heat stress of summer season on productive and reproductive performance. Increase disease incidence, blood system impaired, mortality, decreased fertility, reduced reproductive efficiency are the most obvious sings of heat stress, all of which adversely affect production economics (Bani et al., 2005 and Marai et al., 2006). So that, using some natural nutrient additives were practiced to improve the productive performance. 
Several attempts have been made to improve rabbit's production using various commercial growth promoters (Ashour et al., 2004 and Morsy et al., 2012). Ibrahim et al. (2005) and El-Kholy et al. (2008a and b) showed that Arak (Salvadora persica) can be used as an alternative growth promoter as it enhanced immune function and favored meat quality in growing rabbits. Arak stems are obtained from the roots of Arak, which grows in the area around Mecca and the Middle East area in general. It has medicinal value in manifold uses. Arak contains more than 10 different natural chemical compounds: fluoride, tannins, resins, alkaloids -Salvadoricine-, volatile oils -sinigrin-, sulfur,vitamin $\mathrm{C}$, sodium bicarbonate, chlorides, calcium, benzylisothiocyanate and others, including silica -salicylic acid-, sterols, trimethylamine, saponins and flavonoid (Akhtar and Ajmal, 1981 and Hattab, 1997). Five flavonoid compounds (kaempferol, quercetin, quercetrin, rutin and quercetin glucoside) were isolated from the root of this plant (Islam et al., 2000). Flavonoids have antibacterial, astringent, detergent and abrasive properties (Almas and Stakiw, 2000 and Almas, 2002). Besides flavonoids, both polyphenolic compounds and certain alkaloids seem to stimulate immune function, reduce cholesterol level and play a role in prevent number of chronic diseases such as cancer and cardiovascular disease in rabbits (Jeon et al., 2001 and Yousef et al., 2004). The purpose of the present study was to evaluate how various productive traits, haematological and biochemical indices and thermo-regulation responses of growing NZW rabbits are affected by season; Arak inclusion as a dietary supplement and their interactions.

\section{MATERIALS AND METHODS}

The study was carried out at Sakha Experimental Station, belongs to Animal Production Research Institute, Ministry of Agriculture, Egypt during the breeding season from December to February (winter) and from June to August, (summer). Averages of ambient temperature $\left(\mathrm{AT},{ }^{\circ} \mathrm{C}\right.$ ) and relative humidity $(\mathrm{RH}, \%)$ inside building were recorded weekly. Then, the temperature humidity index (THI, units) was calculated using the equation modified by Marai et al. (2001) as follow:

$\mathrm{THI}=\mathrm{db}^{\circ} \mathrm{C}-\left[(0.31-0.31 \times \mathrm{RH} \%) \times\left(\mathrm{db}^{\circ} \mathrm{C}-14.4\right)\right]$

Where: $\mathrm{db}{ }^{\circ} \mathrm{C}=$ dry bulb temperature in Celsius, $\mathrm{RH} \%=$ relative humidity percentage.

The values obtained are then classified as absence of heat stress $(<27.8)$, moderate heat stress (27.8-28.8), severe heat stress (28.9-29.9) and very severe heat stress $(>30.0)$.

Experimental design :

Ninety-six weaned NZW rabbit aged 30 day were used during winter and summer seasons. Through each season, two groups were used; the first group was fed ad libitum a commercial pelleted diet according to NRC (1977) recommendations and was kept untreated to serve as a control, while the other group was fed the same diet, but supplemented with $0.2 \%$ dried Arak powder. Chemical composition of Arak was determined in duplicate according to AOAC (2006), containing (\% DM): 27.9 ash, 12.4 crude protein, 1.71 ether 
extract, 50.0 nitrogen free extract and 7.95 crude fiber. The ingredients and chemical analysis of the experimental diets are shown in Table 1. The Arak stems were cut into small pieces and allowed to dry at room temperature for 2 days, then ground to powder in a ball mill. All the experimental animals were healthy and were kept under the same management and hygienic conditions.

Table 1: Ingredients and calculated chemical analysis of the pelleted diet fed to growing rabbits.

\begin{tabular}{lc}
\hline \multicolumn{1}{c}{ Items } & $\%$ \\
\hline Ingredients & \\
Clover hay & 30.00 \\
Wheat bran & 26.20 \\
Barley grain & 23.00 \\
Soybean meal (44\%) & 16.00 \\
Molasses & 3.00 \\
Limestone, sodium chloride & 1.5 \\
Vitamins and mineral premix ${ }^{2}$ & 0.30 \\
Calculated analysis ${ }^{2}$ & \\
Crude protein \% & \\
Ether extract \% & 16.72 \\
Crude fibre \% & 2.95 \\
Digestible energy, kcal/kg ${ }^{3}$ & 13.07 \\
${ }^{1}$ Vitamins and minerals premix per kilogram diet contains: &
\end{tabular}

Vit. A, 6000.0 IU; Vit. D, 900.0 IU; Vit. E, 40.0 mg; Vit. K 32.0 mg; Vit. $B_{1}, 2.0 \mathrm{mg}$; Vit. $B_{2}, 4.0 \mathrm{mg}$; Vit. $B_{6}, 2.0 \mathrm{mg}$; Vit. $B_{12}, 10.0 \mu \mathrm{cg}$; Nicotinic acid, $50.0 \mathrm{mg}$; Biotin, $50.0 \mu \mathrm{cg}$; Folic acid, $10.0 \mathrm{mg}$; Choline chloride, $250.0 \mathrm{mg}$; Zinc, $50.0 \mathrm{mg}$; Manganese, $85.0 \mathrm{mg}$; Iron, $50.0 \mathrm{mg}$; Copper, $5.0 \mathrm{mg}$; lodine, $0.2 \mathrm{mg}$; Selenium, $0.1 \mathrm{mg}$; Cobalt, $0.1 \mathrm{mg}$.

${ }^{2}$ According to NRC (1977) for rabbits.

${ }^{3}$ Digestible energy $(\mathrm{kcal} / \mathrm{kg} \mathrm{DM})=4253-32.6 \mathrm{CF}(\% \mathrm{DM})-114.4$ Ash (\% DM). According to Fekete and Gippert (1986).

\section{Experimental procedure :}

Productive traits :

The averages of daily weight gain (DWG, g) and daily feed intake (DFI, g) were calculated weekly for each rabbit during the growing period (12 week). Feed efficiency (FE, g/g) was calculated as a ratio of $\mathrm{g}$ gain $/ \mathrm{g}$ feed. At the ends of the experiment, ten rabbits from each experimental group were randomly taken for slaughter after being fasted for 12 hours. After complete bleeding, the carcass, head, kidneys, liver, heart and lungs were weighed and dressing percentage was calculated. Also, feeding economic efficiency (EE) was calculated and carried out according to the prices of feed ingredients. 


\section{Thermo-respiratory responses:}

Ear lobe "ELT, ' $\mathrm{C}$ " (in the central area of the auricle); skin "ST, ${ }^{\circ} \mathrm{C}$ " (between neck and lion, medial dorsal surface) and rectal (RT, ${ }^{\circ} \mathrm{C}$ ) temperatures were determined by using digital thermometer. Rectal temperature was obtained gently by inserting the clinical thermometer for 2-3 $\mathrm{cm}$ in the rectum for 2 minutes. Respiration rate (RR, breaths/minute) was determined by counting the frequencies of flank movement in the minute. All Body temperatures and respiration rates were weekly measured individually at mid-day (between 12 to $3 \mathrm{pm}$ ). All possible precautions were taken in consideration to avoid disturbing the animal, including counting the respiration breaths, just before measuring the body temperatures.

Blood sampling and analyses :

Immediately after slaughtering, blood samples were collected from the four rabbits per each experimental group. The samples were collected into dry clean centrifuge tubes, the serum was separated by centrifugation at 3000 r.p.m. for 20 minutes and kept in a deep freezer at $-20^{\circ} \mathrm{C}$ until biochemical analysis. Non-coagulated blood was tested shortly after collection for determination blood pictures including, red blood cells count (RBCs, $10^{6} / \mathrm{mm}^{3}$ ), white blood cells count (WBCs, $\left.10^{3} / \mathrm{mm}^{3}\right)$; hemoglobin $(\mathrm{Hb}$, $\mathrm{g} / \mathrm{dl})$ concentration and hematocrite value ( $\mathrm{Ht}, \%)$ according to Drew et al. (2004). Total protein (TP, g/dl) and albumin (Alb, g/dl) levels were determined using commercial kits supplied by Randox (Randox Laboratories Ltd, Crumlin, Co, Antrim, UK) according to Henry et al. (1974). Globulin (Glb, g/dl) concentration was estimated by subtracting the values of Alb from the corresponding values of TP. Serum samples were analyzed for determinations of aspartate amino transferase (AST, U/L) and alanine amino transaminase (ALT, U/L) using commercial kits (Linear Chemicals, Barcelona, Spain) according to the manufacturer procedure.

Statistical analysis:

Data of the experiment was statistically analyzed according to SPSS (2012) computer program using the following fixed model :-

$$
Y_{i j k}=\mu+S_{i}+T_{j}+S T_{i j}+e_{i j k}
$$

Where: $Y_{\mathrm{ijk}}=$ an observation; $\mu=$ the overall mean, common element to all observations; $S_{i}=$ the fixed effect of the season ( $i=1$ "winter" and 2 "summer); $\mathrm{T}_{\mathrm{j}}=$ the fixed effect of treatment ( $\mathrm{j}=1$ "control" and 2 "treated"); $\mathrm{ST}_{\mathrm{ij}}=$ the interaction effect between $\mathrm{i}^{\mathrm{t} \text { th }}$ season and $\mathrm{j}^{\text {th }}$ treatment; and $\mathrm{e}_{\mathrm{ijk}}=$ random error component assumed to be normally distributed. Data presented as percentages were transformed to the corresponding arcsine values (Warren and Gregory, 2005) before being statistically analyzed. The differences among means were tested using Duncan's New Multiple Range Test (Duncan, 1955). All data are presented least square means.

\section{RESULTS AND DISCUSSION}

\section{Climatic conditions:}

Averages of $\mathrm{AT}, \mathrm{RH}$ and $\mathrm{THI}$ during the whole experimental period are shown in Table 2. The THI data clearly indicated an absence of heat stress conditions (less than 27.8) during winter season. While during the summer season rabbits were exposed to moderate heat stress according to estimated 
THI value (28.8). It was suggested that the optimal temperature humidity index for the rabbit husbandry is 27.8 (Marai et al., 2002).

Table 2: Averages of ambient temperature (AT, $\left.{ }^{\circ} \mathrm{C}\right)$, relative humidity (RH, \%) and temperature humidity index (THI, units) during winter and summer season.

\begin{tabular}{llccc}
\hline Season & Months & AT $\left({ }^{\circ} \mathbf{C}\right)$ & RH (\%) & THI (Units) \\
\hline Winter & December & $18.0 \pm 0.44$ & $71.0 \pm 1.00$ & $17.7 \pm 0.43$ \\
& January & $19.5 \pm 0.45$ & $72.3 \pm 1.01$ & $19.1 \pm 0.44$ \\
& February & $20.2 \pm 0.42$ & $71.2 \pm 1.03$ & $19.7 \pm 0.44$ \\
\multirow{3}{*}{ Summer } & Average & $19.2 \pm 0.43$ & $71.5 \pm 1.02$ & $18.8 \pm 0.43$ \\
& June & $29.6 \pm 0.52$ & $69.3 \pm 0.61$ & $28.2 \pm 0.57$ \\
& July & $29.8 \pm 0.51$ & $71.0 \pm 0.57$ & $28.4 \pm 0.56$ \\
& August & $31.6 \pm 0.55$ & $68.5 \pm 0.68$ & $29.9 \pm 0.55$ \\
& Average & $30.3 \pm 0.53$ & $69.6 \pm 0.63$ & $28.8 \pm 0.56$ \\
\hline
\end{tabular}

\section{Growth performance and feed efficiency:}

\section{Season effect:}

Results in Table 3 showed significant differences $(P \leq 0.05)$ between season groups in growth performance and feed efficiency of weaned NZW rabbits. Elevating THI during summer season decreased significantly $(P \leq 0.05)$ growth performance and feed efficiency of weaned NZW rabbits. These results agreed with those of Marai et al. (2006) and Ondruska et al. (2011). On the other hand, these results are different than what has been observed by Daader et al. (1999) who showed that difference in DWG between summer and winter was not significant. However, several authors found that feed intake decreased by $40-50 \%$ at $30-32{ }^{\circ} \mathrm{C}$ (Rafai and Papp, 1984 and Wittorf et al., 1988) and by $30 \%$ in summer than in winter (Marai et al., 1994) and in hot $\left(>32^{\circ} \mathrm{C}\right)$ conditions (Hermes et al., 1999). The reduction of DFI under summer conditions in the present study may be due to that the high ambient temperature stimulates the thermal receptors center in the hypothalamus causing a decrease in feed intake as mentioned by Marai et al. (1994 and 2006). In contrast, the increased feed intake during winter may be due to increase the appetite of rabbits (Ashour et al., 2005). Exposure to high ambient temperature pushes rabbits to balance the excessive heat load by using different means to dissipate, as much as possible, their latent heat. If such means fail, rabbits use strategies that include: depression in feed intake (Okab et al., 2008). The reduction in DWG during summer season was due to a drastic decrease in rabbit DFI and FE compared with winter season, which might have led to less protein biosynthesis and less fat deposition (Okab et al., 2008; Ogunjimi et al., 2008). In addition, Bahga et al. (2010) showed that heat stress leads to decreased performance of rabbits in terms of decreased growth rate and feed intake.

\section{Treatment effect:}

Data presented in table 3 showed that, DWG, final BW at 12 week, and feed efficiency values of growing NZW rabbits fed diet supplemented with $0.2 \%$ Arak were significantly $(P \leq 0.05)$ higher during winter and summer season compared to control group. No effect was detected on DFI, which on 
average was $97.4 \mathrm{gm} /$ day. These results are similar to that reported by Ibrahim et al. (2005) and El-Kholy et al. (2008a).

The significant $(P \leq 0.05)$ increase in DWG for rabbits received Arak at $0.2 \%$ level could be due to the better absorption of protein (Ibrahim et al., 2005), bactericidal, antimycotic or antifungal properties of Arak as reported by Al-Samh and Al-Bagieh (1996). Also, vitamin C, which is presence in Arak, has important role in various metabolic processes in the body via its regulation effect on thyroid and adrenal glands function (McDowell, 2000). This fact can explain the increase in live BW of treated group. Beside that, sodium bicarbonate showing growth promoting response in most instances when included in diets of rabbits (Al-Shanti, 2003). On the other hand, the minerals content in Arak (calcium, fluorine, and sulphur) can form structural components of body organs and tissues (Suttle, 2010). In addition, the increased in values of blood biochemical parameters in the treated groups as mentioned later, may be the reason of increased in growth performance, whereas, Al-Eissa (2011) showed that biochemical parameters could be used to assess the metabolic condition of rabbits.

Table 3: Effect of season, Arak treatment and their interactions on growth performance of growing NZW rabbits through the experimental period.

\begin{tabular}{|c|c|c|c|c|c|}
\hline \multirow[b]{2}{*}{ Factors } & \multicolumn{5}{|c|}{ Parameters $^{1}$} \\
\hline & IBW (g) & DWG (g) & DFI (g) & FBW (g) & FE (g/g) \\
\hline Season & * & ** & * & ** & * \\
\hline Winter (W) & $601.79 \pm 10.22$ & $21.31 \pm 1.09$ & $101.16 \pm 2.53$ & $1752.15 \pm 17.71$ & $0.211 \pm 0.09$ \\
\hline Summer (S) & $570.94 \pm 11.75$ & $19.48 \pm 1.30$ & $93.67 \pm 2.86$ & $1622.99 \pm 22.92$ & $0.207 \pm 0.09$ \\
\hline Treatment: & NS & * & NS & ** & ** \\
\hline Control (C) & $587.24 \pm 11.21$ & $18.91 \pm 1.16$ & $97.57 \pm 2.74$ & $1608.43 \pm 18.04$ & $0.194 \pm 0.09$ \\
\hline Treated (T) & $585.50 \pm 11.26$ & $21.87 \pm 1.27$ & $97.27 \pm 2.77$ & $1766.71 \pm 20.60$ & $0.224 \pm 0.09$ \\
\hline Interactions : & * & ** & * & ** & ** \\
\hline $\mathrm{W} \times \mathrm{C}$ & $602.63 \pm 17.03^{a}$ & $20.09 \pm 1.40^{c}$ & $102.50 \pm 3.53^{a}$ & $1687.65 \pm 19.97^{b}$ & $0.196 \pm 0.01^{b}$ \\
\hline $\mathrm{S} \times \mathrm{C}$ & $571.84 \pm 14.26^{b}$ & $17.73 \pm 1.68^{d}$ & $92.64 \pm 4.01^{\mathrm{b}}$ & $1529.21 \pm 19.66^{c}$ & $0.191 \pm 0.01^{c}$ \\
\hline$W \times T$ & $600.95 \pm 11.70^{a}$ & $22.51 \pm 1.62^{a}$ & $99.82 \pm 3.67^{a}$ & $1816.65 \pm 22.82^{a}$ & $0.225 \pm 0.01^{a}$ \\
\hline $\mathrm{S} \times \mathrm{T}$ & $570.04 \pm 19.00^{b}$ & $21.24 \pm 1.89^{b}$ & $94.71 \pm 4.16^{b}$ & $1716.77 \pm 31.57^{b}$ & $0.224 \pm 0.01^{a}$ \\
\hline
\end{tabular}

${ }^{1}$ IBW= initial body weight, DWG=daily weight gain, DFI=daily feed intake, FBW=final body weight, and $F E=$ feed efficiency.

NS= Not Significant; ${ }^{*}=\mathrm{P} \leq 0.05 ;{ }^{* *}=\mathrm{P} \leq 0.01$.

$a, b, c, d$ Means bearing different letters in the same column significantly differed within each factors $(\mathrm{P} \leq 0.05)$.

\section{Effect of interactions:}

Interactions between season and Arak supplementation effects were significantly $(P \leq 0.01)$ on final BW, DWG and FE of NZW rabbits as shown in Table 3. The magnitude of improvement was the highest with Arak treatment in winter. At the same time, there were negative interaction effects of the Arak treatment on the DFI in two seasons. It is interesting to observe the insignificant differences in FBW between treated rabbits under summer season $(S \times T)$ and those untreated under winter season $(W \times C)$. Beside that, Arak addition for rabbits reared during summer season ( $\mathrm{S} \times \mathrm{T}$ ) recorded insignificant differences in $\mathrm{FE}$ compared to those received the same treatment under winter season $(\mathrm{W} \times \mathrm{T})$. So, dietary addition of heat-stressed 
growing rabbits with $0.2 \%$ Arak restored the loss pertaining to heat stress and surpassed the winter control in DWG, FE and FBW.

Blood parameters:

Hematological indices:

Season effect:

Values of blood picture including RBCs, WBCs and $\mathrm{Hb}$ were significantly higher $(P \leq 0.05)$ in rabbits reared in winter season than those in summer season (Table, 4). This indicates the negative effects of summer heat stress on hematological parameters which reported by many authors (Marai et al., 2002; Okab et al., 2008 and Al-Eissa, 2011). Also, these results are in agreement with the findings of Möstl and Palme (2002) who reported that heat stress in animals decreased the level of adrenocorticotropic hormone (ACTH), which might then result in decreases in RBC counts, $\mathrm{Ht}$ and $\mathrm{Hb}$ concentration. In addition, the depression of $\mathrm{Ht}$ during summer season was also reported to be related to a reduction in cellular oxygen requirement for reducing metabolic heat production in order to compensate the elevated environmental heat load (Okab et al., 2008). Herz and Shenhauf (1985) showed that the high temperature may induce haemodilution and increase of break-down in erythrocytes. Ashour et al. (2004) demonstrated that the reduction in $\mathrm{Hb}$ and $\mathrm{Ht}$ could be attributed to the increase of plasma volume by water retention to enable proper water supply for evaporation as the major way for heat dissipation in hot conditions. Such an effect could be mainly attributed to elevated THI during summer season, which could cause an increase in blood viscosity leading to allergic effects and induction of WBC production in animals (Lee et al., 1976). In general, haematological changes seem to play an important role in adjusting the rabbit's physiology during elevated THI.

\section{Effect of treatment:}

Table 4 showed that, the values of blood picture including RBCs, WBCs, $\mathrm{Hb}$ and $\mathrm{Ht}$ were significantly higher $(\mathrm{P} \leq 0.05)$ in supplemented growing $\mathrm{NZW}$ rabbits with $0.2 \%$ Arak than those in control group. However, these high values are still within the normal ranges. The trends resulting from adding Arak in the present study are in agreement with study by (Ibrahim et al., 2005 and El-Kholy et al., 2008b).

The improvements in the blood hematological values as a result of treatment with Arak may be due to improvement in the immune response (minerals and flavonoids have a role in enhancing immune system). Inclusion of minerals in Arak (calcium, $582 \mu \mathrm{g} / \mathrm{ml}$; fluorine, $0.07 \mu \mathrm{g} / \mathrm{ml}$; and sulphur, $34 \mathrm{~g} / \mathrm{ml}$ ) and flavonoid compounds, (kaempferol, quercetin, quercetrin, rutin and quercetin glucoside) as mentioned by Hattab (1997) and Islam et al. (2000) may have a role in improvements of these hematological traits. Ingestion of Arak has a good effect on the composition of blood (Ibrahim et al., 2005 and El-Kholy et al., 2008b). Additionally, McDowell (2000) suggested that bioflavonoids are a special class of nutrients important in diminishing capillary fragility, preserving blood cell integrity, enhancing blood circulation and anti-bacterial activity. The body becomes more susceptible to bruising and hemorrhaging when capillaries lose their physical integrity and when tissues have become weakened, the body was vulnerable 
to allergies and immune system breakdown. The same author added that bioflavonoids and vitamin C worked synergistically to maintain blood capillary health and prevent capillary fragility. In general, Arak inclusion causes an increase in total RBC's, which in turn caused an increase in $\mathrm{Hb}$ values. This is due to the positive relationships between RBC's and $\mathrm{Hb}$ (Nowaczewski and Kontecka, 2012). This indicates the positive effects of this addition on hematological parameters and the positive impact on liver and spleen, as well as, other tissues like bone marrow where RBCs are synthesized (Feldman et al., 2000).

Finally the improvements in blood picture can be reflected positively on the immune system.

\section{Effect of interactions:}

Interactions effects between season and Arak supplementation were significantly high $(\mathrm{P} \leq 0.05$ and $\mathrm{P} \leq 0.01)$ on $\mathrm{RBCs}, \mathrm{WBCs}, \mathrm{Hb}$ and $\mathrm{Ht}$ values (Table 4). The highest values of all hematological values were recorded for rabbits treated with dietary Arak during winter season. While the lowest values were observed for those fed the control diet during summer season. These result proved Arak treatment can be help to counteract stress and enhance hematological traits with high of THI during summer season. The increase of RBC's in treated rabbits during summer season can be discussed from the point that Arak as bioantioxidant may be covered the reduction in body antioxidant under heat stress (Chew, 1995 and Abdel-Monem et al., 2013). However, Bobyrev et al. (1988) found that free radical oxidation of lipids, lipoproteins and peroxide hemolysis of erythrocytes increased in rabbits given diets devoid of antioxidants.

Table 4: Effect of season, Arak treatment and their interactions on blood picture of growing NZW rabbits.

\begin{tabular}{|c|c|c|c|c|}
\hline Factors & $\begin{array}{l}\text { Red blood cells } \\
\left(10^{6} / \mathrm{mm}^{3}\right)\end{array}$ & $\begin{array}{c}\text { White blood cells } \\
\left(10^{3} / \mathrm{mm}^{3}\right)\end{array}$ & $\begin{array}{l}\text { Hemoglobin } \\
\text { (g/dl) }\end{array}$ & $\begin{array}{c}\text { Hematocrite } \\
(\%)\end{array}$ \\
\hline Season & $*$ & * & ** & ** \\
\hline Winter (W) & $6.47 \pm 0.06$ & $7.77 \pm 0.07$ & $12.12 \pm 0.10$ & $40.40 \pm 0.37$ \\
\hline Summer (S) & $5.55 \pm 0.06$ & $6.51 \pm 0.07$ & $9.64 \pm 0.10$ & $35.90 \pm 0.37$ \\
\hline Treatment: & * & * & * & ** \\
\hline Control (C) & $5.81 \pm 0.06$ & $6.74 \pm 0.07$ & $10.42 \pm 0.11$ & $36.66 \pm 0.37$ \\
\hline Treated $(\mathrm{T})$ & $6.21 \pm 0.06$ & $7.54 \pm 0.07$ & $11.34 \pm 0.11$ & $39.63 \pm 0.37$ \\
\hline Interactions : & * & * & $* *$ & ** \\
\hline$W \times C$ & $6.21 \pm 0.08^{b}$ & $7.36 \pm 0.10^{b}$ & $11.62 \pm 0.15^{b}$ & $39.06 \pm 0.52^{b}$ \\
\hline$S \times C$ & $5.41 \pm 0.08^{d}$ & $6.11 \pm 0.10^{d}$ & $9.22 \pm 0.15^{\mathrm{d}}$ & $34.26 \pm 0.52^{d}$ \\
\hline$W \times T$ & $6.72 \pm 0.08^{a}$ & $8.17 \pm 0.10^{a}$ & $12.61 \pm 0.15^{a}$ & $41.73 \pm 0.52^{\mathrm{a}}$ \\
\hline$S \times T$ & $5.69 \pm 0.08^{c}$ & $6.91 \pm 0.10^{c}$ & $\begin{array}{l}10.06 \pm 0 . \\
15^{c}\end{array}$ & $\begin{array}{l}37.53 \pm 0.5 \\
2^{c}\end{array}$ \\
\hline
\end{tabular}

a, $b, c, d$ Means bearing different letters in the same column significantly differed within each factors $(P \leq 0.05)$. 


\section{Blood biochemical parameters: \\ Season effect:}

Serum TP, Alb, Glb, AST and ALT were significantly $(P \leq 0.05)$ higher in winter than in summer seasons (Table 5). These changes in the blood biochemical parameters of the heat stressed rabbits was similar to that of Marai et al. (2002); Okab et al. (2008); Al-Eissa (2011) and Abdel-Monem et al. (2013) who found that blood biochemical parameters were significantly lower $(P \leq 0.01)$ in rabbits which exposed to the heat stress in summer season.

The decrease in serum TP for weaned NZW rabbits in summer season group may be due to the decrease in DFI and dilution of serum proteins or both (Ondruska et al., 2011). Also, the decrease in the protein synthesis can be due to a depression of anabolic hormonal secretion such as growth hormone, thyroxine and insulin (Ondruska et al., 2011) or the increase in catabolic hormones (glucocorticoids and catecholamines) and decrease in concentration of serum transaminase enzymes (Ayyat and Marai, 1996). Amici and Merendino (1996) demonstrated that the decrease of TP has to be considered as an important biological indicator of deficiency in activity of the immune system function in heat stressed rabbits.

\section{Effect of treatment:}

Addition Arak caused significant increases the averages of TP, Alb, Glb, AST and ALT by about 22.5, 24.5, 18.7, 21.9 and $14.6 \%$ than the control, respectively, but these increases were still within normal range as indicated by the non-sign of toxicity (Table, 5). These results are in harmony with findings of El-Kholy et al. (2008b).

Concerning the effects of Arak treatment on TP and its fractions (Alb and $\mathrm{Glb}$ ), it can be explained and interpreted the improvements in their profile in the present study to the increasing animal resistance to any physiological or physical stress. However, serum TP level is a general indication of immune status (White et al., 2002). Also, increased globulin concentration with Arak inclusion as observed in the present study may be an indication of increased immunity in the rabbits since the liver will be able to synthesize enough globulins for immunologic action as mentioned by Sunmonu and Oloyede (2007). The increase in serum TP and Glb concentrations in rabbits supplemented with $0.2 \%$ Arak can be due to increase protein synthesis in this supplemented group over the control group.

\section{Effect of interactions:}

Untreated growing rabbits during the summer season had lower $(P \leq 0.01)$ values of TP, Alb, AST and ALT concentrations than the other three interactions (Table 5). Also, it's so clear that, concentrations of Alb, Glb and ALT concentrations due to Arak inclusion during summer season $(S \times T)$ were closed (insignificant differences) to those untreated during winter season $(\mathrm{W} \times \mathrm{C})$. This result proves that Arak has valuable and precious effect under adverse hot conditions as in summer season rather than comfortable conditions as in winter season. Because of environmental stress causes an increase in the oxidative stress so, antioxidant nutrient supplementation protects against the oxidative DNA damage through its free radical scavenging activity (Lee, 2002). 
Table 5: Effect of season, Arak treatment and their interactions on some blood metabolic and enzymatic profiles of growing NZW rabbits.

\begin{tabular}{|c|c|c|c|c|c|}
\hline Factors & $\begin{array}{l}\text { Total } \\
\text { protein } \\
\text { (g/dl) }\end{array}$ & $\begin{array}{l}\text { Albumin } \\
\text { (g/dl) }\end{array}$ & $\begin{array}{l}\text { Globulin } \\
\text { (g/dl }\end{array}$ & $\begin{array}{c}\text { Aspartate } \\
\text { aminotransferase } \\
\text { (U/L) }\end{array}$ & $\begin{array}{c}\text { Alanine } \\
\text { aminotransferase } \\
\text { (U/L) }\end{array}$ \\
\hline Season & * & * & * & $*$ & $*$ \\
\hline Winter (W) & $7.50 \pm 0.50$ & $5.25 \pm 0.42$ & $2.25 \pm 0.13$ & $25.30 \pm 1.73$ & $16.43 \pm 0.64$ \\
\hline Summer (S) & $6.14 \pm 0.28$ & $4.18 \pm 0.24$ & $1.97 \pm 0.09$ & $22.36 \pm 1.15$ & $14.15 \pm 0.78$ \\
\hline Treatment: & * & * & * & * & * \\
\hline Control (C) & $6.13 \pm 0.31$ & $4.20 \pm 0.25$ & $1.93 \pm 0.12$ & $21.48 \pm 1.57$ & $14.25 \pm 0.80$ \\
\hline Treated (T) & $7.51 \pm 0.48$ & $5.23 \pm 0.41$ & $2.28 \pm 0.11$ & $26.18 \pm 1.31$ & $16.33 \pm 0.62$ \\
\hline Interactions : & ** & $* *$ & * & * & * \\
\hline $\mathrm{W} \times \mathrm{C}$ & $7.72 \pm 0.45^{a}$ & $5.20 \pm 0.35^{b}$ & $2.02 \pm 0.18^{b}$ & $24.85 \pm 2.59^{c}$ & $15.90 \pm 0.96^{b}$ \\
\hline $\mathrm{S} \times \mathrm{C}$ & $5.05 \pm 0.27^{c}$ & $3.19 \pm 0.19^{c}$ & $1.86 \pm 0.14^{c}$ & $18.12 \pm 1.47^{d}$ & $12.60 \pm 1.19^{c}$ \\
\hline$W \times T$ & $7.80 \pm 0.90^{\mathrm{a}}$ & $5.30 \pm 0.77^{a}$ & $2.50 \pm 0.18^{a}$ & $25.75 \pm 2.37^{a}$ & $16.95 \pm 0.85^{a}$ \\
\hline $\mathrm{S} \times \mathrm{T}$ & $7.23 \pm 0.35^{\mathrm{b}}$ & $5.16 \pm 0.31^{\mathrm{b}}$ & $2.07 \pm 0.13^{b}$ & $26.60 \pm 1.17^{b}$ & $15.71 \pm 0.91^{b}$ \\
\hline
\end{tabular}

* $=\mathrm{P} \leq 0.05 ;$ ** $=\mathrm{P} \leq 0.01$.

$a, b, c, d$ Means bearing different letters in the same column significantly differed within each

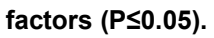

Carcass traits:

Season effect:

Table 6 shows that season had significant $(P \leq 0.01)$ effect on carcass traits. However, rabbits in winter season showed higher significant $(P \leq 0.01)$ values of carcass weight, dressing percentage and internal organs weight than those in summer season. These results agree with the findings of Zeferino et al. (2013) on rabbits. These might be due to reduced DFI and deterioration of DWG (Table 3 ) resulted in stressful hot conditions during summer season. On the hand, Marai et al. (2006) showed insignificant differences in carcass traits between summer and winter season except in head and hind weight.

\section{Effect of treatment:}

The effect of Arak treatment on carcass traits was so clear (Table 6), where treatment caused $35 \%$ and $6.7 \%$ significant $(P \leq 0.05)$ increase in carcass weight and dressing\% in winter comparable with summer, respectively. These results are in harmony with the findings of Al-Shanti (2003); Marai et al. (2006) and Abdel-Monem et al. (2013) under different nutritional conditions. The increase in carcass traits for treated group may be mainly related to the increase in growth performance. Therefore, preslaughter weight is considered to be one of the most important factor affecting carcass traits in rabbits.

\section{Effect of interaction:}

Concerning, season and dietary Arak supplementation interactions effects, it is clear that, the highest values of relative weights of carcass, dressing $\%$ and internal organs relative weights were recorded for rabbits treated with dietary Arak during winter season. While the lowest values were observed for those fed the control diet during summer season. Analysis of variance showed significant differences $(P \leq 0.01$ and $P \leq 0.05)$ in interactions for all carcass traits. 
J. Animal and Poultry Prod., Mansoura Univ., Vol. 5 (5), May, 2014

6 
On the other hand, Arak treatment caused 8.4 and $25.4 \%$ significant $(P \leq 0.05)$ increase in carcass weight and 1.9 and 7.3 in dressing\% in winter comparable to the summer, respectively. This result is another evidence of the privilege of Arak during summer season than the winter season.

Thermo-respiratory responses:

Season effect:

The lowest values of RR, RT, ST and ELT were recorded for rabbits reared during winter season compared to those in summer season (Table, 7). These results are fairly agreement with those reported by Habeeb et al. (1998). These differences among the two seasons could be attributed to the variations in the $\mathrm{THI}$, as reflection to climatic temperature alongside the humidity percentage. However, rising blood temperature as a result of exposure to elevated ambient temperature is known to influence body temperature regulation center in the brain (Glue and Hardy, 1970). In addition, they showed that the first response of the animal under hot conditions is to elevate ST by vasodilatation in skin to bring more heat from the core by much and fast circulating blood to the skin. It could be observed from the results that, ear lobe temperature was always lower than both rectal and skin temperature by about $5^{\circ} \mathrm{C}$ this may be due to the important role of the ear in body thermoregulation in rabbits (Lebas et al., 1997). Increase in body temperature and respiration rate are the most important signs of heat stress in farm animals. The increase in body temperature during summer season is associated with a marked reduction in feed intake (Ashour et al., 2005) and redistribution of blood flow (Khodaei-Motlagh et al., 2011), which can negatively affect the body thermoregulation of the animals. Finally, high thermal and respiratory parameters of growing NZW rabbits during summer season may be related to the expected high peripheral blood flow (vasodilatation) to increase heat loss.

\section{Effect of treatment:}

The results given in Table 7 showed that values of RR, RT, ST and ELT significantly decreased $(P \leq 0.05)$ with dietary Arak inclusion compared to control group by about, $2.6,0.6,0.9$ and $0.7 \%$, respectively. It seems that the literature is still nihilistic on the effect of Arak on rabbit's thermo-respiratory responses. These results are in agreement with the findings of Abdel-Samee et al. (2003) and Ashour et al. (2004) under different nutritional conditions.

Differences between control and treated groups can be due to the rich components in Arak. However, chloride maintains osmotic pressure, regulate acid-base equilibrium and control water metabolism in the body (Suttle, 2010). On the other hand, respiration is based on the chloride shift, whereby the potassium salt of oxyhaemoglobin exchanges oxygen $\left(\mathrm{O}_{2}\right)$ for carbon dioxide $\left(\mathrm{CO}_{2}\right)$ via bicarbonate in the tissue and reverses that process in the lung, where reciprocal chloride exchanges maintain the anion balance (Block, 1994). Moreover, Morsy et al. (2012) reported that the role of ascorbic acid in this situation may be due to reducing the effects of stress, increasing the immunological traits and its growth-promoting effect.

It is clear from this study that Arak addition provides comfortable thermo-respiratory responses to counteract summer heat stress. Under such condition the animals are exempted from doing exhaustive physiological 
activities to maintain their normal set-up biological functions. Consequently their productive and physiological performances will be good.

Effect of interaction:

Concerning, season and dietary Arak supplementation interactions effects, it is clear that, the highest values of thermo-respiratory responses were recorded for untreated rabbits during summer season. While the lowest values were observed for those fed dietary Arak addition during winter season. Analysis of variance showed significant differences $(P \leq 0.01$ or $\mathrm{P} \leq 0.05)$ in interactions for all body thermoregulation traits. Also, results demonstrated that rabbits treated with Arak in summer season keep rabbit's RR, RT and ST nearly to that of the untreated group in the winter season. This is assured by the insignificant difference, for RR, RT and ST values, between $(\mathrm{W} \times \mathrm{C})$ and $(\mathrm{S} \times \mathrm{T})$. This is another confirmation that treatment with Arak was more efficient and beneficial under harsh and bad conditions (THI>27.8) rather than best and comfort conditions.

Table 7: Effect of season, Arak treatment and their interactions on some

\begin{tabular}{|c|c|c|c|c|}
\hline Factors & $\begin{array}{l}\text { Respiration rate } \\
\text { (breaths/minute) }\end{array}$ & $\begin{array}{c}\text { Rectal } \\
\text { temperature } \\
\left({ }^{\circ} \mathrm{C}\right)\end{array}$ & $\begin{array}{c}\text { Skin } \\
\text { temperature } \\
\left({ }^{\circ} \mathrm{C}\right)\end{array}$ & $\begin{array}{c}\text { Ear lobe } \\
\text { temperature }\left({ }^{\circ} \mathrm{C}\right)\end{array}$ \\
\hline Season & ** & ** & * & * \\
\hline Winter (W) & $179.25 \pm 1.78$ & $39.10 \pm 0.37$ & $37.95 \pm 0.36$ & $32.05 \pm 0.31$ \\
\hline Summer (S) & $189.20 \pm 1.78$ & $39.67 \pm 0.37$ & $38.00 \pm 0.36$ & $32.35 \pm 0.31$ \\
\hline Treatment: & $* *$ & ** & ** & * \\
\hline Control (C) & $188.20 \pm 1.78$ & $39.35 \pm 0.37$ & $38.15 \pm 0.36$ & $32.30 \pm 0.31$ \\
\hline Treated (T) & $183.25 \pm 1.78$ & $39.13 \pm 0.37$ & $37.80 \pm 0.36$ & $32.10 \pm 0.31$ \\
\hline Interactions & ** & ** & * & * \\
\hline \multicolumn{5}{|l|}{ : } \\
\hline $\mathrm{W} \times \mathrm{C}$ & $185.30 \pm 2.52^{b}$ & $39.20 \pm 0.52^{b}$ & $37.80 \pm 0.51^{c}$ & $32.20 \pm 0.44^{c}$ \\
\hline$S \times C$ & $191.10 \pm 2.52^{a}$ & $39.65 \pm 0.52^{a}$ & $38.20 \pm 0.51^{a}$ & $32.40 \pm 0.44^{a}$ \\
\hline$W \times T$ & $179.20 \pm 2.52^{c}$ & $39.16 \pm 0.52^{c}$ & $38.10 \pm 0.51^{b}$ & $31.90 \pm 0.44^{d}$ \\
\hline $\mathrm{S} \times \mathrm{T}$ & $187.30 \pm 2.52^{\mathrm{b}}$ & $39.24 \pm 0.52^{b}$ & $37.80 \pm 0.51^{\mathrm{c}}$ & $32.30 \pm 0.44^{b}$ \\
\hline
\end{tabular}

${ }^{*}=\mathrm{P} \leq 0.05 ;{ }^{* *}=\mathrm{P} \leq 0.01$

$a, b, c, d$ Means bearing different letters in the same column significantly differed within each factors $(P \leq 0.05)$.

\section{Economical evaluation : \\ Effect of season:}

Data concerning economical evaluation are summarized in Table 8. The present results indicate a decrease of net profit for rabbits reared under summer conditions compared to those reared under winter conditions. The decrease in net profit $(9.3 \%)$ was similar to that reported by Ayyat and Marai (1996) and Marai et al. (2006).

\section{Effect of treatment:}

Comparison between control and treated groups, dietary addition with $0.2 \%$ Arak showed the highest net profit (Table 8 ). The present results indicate an improvement in net profit, by about $20.0 \%$, for rabbits fed diet containing Arak compared to those fed diet with no addition. This result is in harmony with those of Marai et al. (2006) and El-Kholy et al. (2014) using different growth promoters for NZW growing rabbits. 


\section{Effect of interaction:}

The highest and pronounced increase of net profit was observed for treated rabbits reared during winter season $(\mathrm{W} \times \mathrm{T})$. While control rabbits reared during summer season was recorded the lowest net profit value. It is interesting to notice that rabbits treated with Arak under summer season ( $\mathrm{S} \times$ T) not only had superior nit profit value compared to those untreated under winter season $(\mathrm{W} \times \mathrm{C})$ but also recorded value closed to those treated under winter season $(\mathrm{W} \times \mathrm{T})$. This is another confirmation that treatment with Arak was more economically and beneficial under harsh and bad conditions rather than best and comfort conditions.

Table 8: Effect of season, Arak treatment and their interactions on economic efficiency of growing NZW rabbits.

\begin{tabular}{|c|c|c|c|c|c|c|}
\hline Factors & $\begin{array}{c}\text { Total feed } \\
\text { intake } \\
\text { /rabbit (kg) }\end{array}$ & $\begin{array}{c}\text { Price/ } \\
\text { kg } \\
\text { diet } \\
(\mathrm{LE})^{1}\end{array}$ & $\begin{array}{c}\text { Total } \\
\text { feed } \\
\text { cost/rab } \\
\text { bit (LE) }\end{array}$ & $\begin{array}{c}\text { Price } / k \\
\text { g body } \\
\text { weight } \\
\text { (LE) }\end{array}$ & $\begin{array}{c}\text { Selling } \\
\text { price (L.E/ } \\
\text { head) }\end{array}$ & $\begin{array}{c}\text { Net } \\
\text { profit of } \\
\text { each } \\
\text { head }^{2}\end{array}$ \\
\hline \multicolumn{7}{|l|}{ Season } \\
\hline Winter (W) & 5.46 & 2.60 & 14.20 & 22.00 & 38.55 & 19.35 \\
\hline Summer (S) & 5.06 & 2.60 & 13.16 & 22.00 & 35.71 & 17.55 \\
\hline \multicolumn{7}{|l|}{ Treatment: } \\
\hline Control (C) & 5.27 & 2.60 & 13.70 & 22.00 & 35.39 & 16.69 \\
\hline Treated $(\mathrm{T})$ & 5.25 & 2.64 & 13.86 & 22.00 & 38.87 & 20.01 \\
\hline \multicolumn{7}{|l|}{ Interactions : } \\
\hline$W \times C$ & 5.54 & 2.60 & 14.40 & 22.00 & 37.13 & 17.73 \\
\hline$S \times C$ & 5.00 & 2.60 & 13.00 & 22.00 & 33.64 & 15.64 \\
\hline $\mathrm{W} \times \mathrm{T}$ & 5.93 & 2.64 & 15.66 & 22.00 & 39.97 & 19.31 \\
\hline$S \times T$ & 5.11 & 2.64 & 13.49 & 22.00 & 37.77 & 19.28 \\
\hline $\begin{array}{l}{ }^{1} \text { The price w } \\
\text { period; L.E } \\
{ }^{2} \text { Net profit of } \\
5 \text { "Conside } \\
\text {.....etc.")] }\end{array}$ & alculated o & the ba & of ingre & its pric & through the & experime \\
\hline
\end{tabular}

\section{CONCLUSION}

It can be concluded that Arak addition to growing rabbit diets exerted benefits on the growth performance, carcass characteristics, some hematological and biochemical parameters and some thermo-respiratory responses. The sum of these benefits was more economically under summer season conditions rather than winter season conditions. Further studies are, however, required to verify the influence of Arak addition on the intestinal mucosa development of growing rabbits.

\section{REFERENCES}

Abdel-Monem, U.M., Huda, Qar and Kandeil, M.A. (2013). Hot climate effects and their amelioration on growth performance, carcass traits, blood constituents and picture of growing kids. J. Appl. Sci. Res., 9: 666-671.

Abdel-Samee, A.M., Ali, A.M., Mousa, M.R.M. and Abdel-Ghaffar, M.A. (2003). Performance of heat stressed New Zealand White (NZW) growing rabbits in subtropics. In Proc.: $9^{\text {th }}$ Conf. on Animal Nutrition (Ruminants, Poultry, Rabbit and Fish Nutrition), 14-17 October, 2003, Hurghada, Egypt, pp. 221-229. 
Akhtar, M.S. and Ajmal, M. (1981). Significance of chewing sticks (miswaks) in oral hygiene from a pharmacological viewpoint. J. Pak. Med. Assoc., 31: 89-95.

Al-Eissa, M. S. (2011). Effect of gestation and season on the haematological and biochemical parameters in domestic rabbit (Oryctolagus cuniculus). British Biotechnol. J., 1: 10-17.

Almas, K. (2002). The effect of Salvadora persica extract (Miswak) and chlorhexidine gluconate on human dentin: A SEM Study. J. Contemp. Dent. Pract., 3: 27-35.

Almas, K. and Stakiw, J.E. (2000). The effect of miswak extract from Salvadora persica stored for 18 years on microbes in vitro. Egyptian Dent. J., 46: 227-30.

Al-Samh, D.A.A. and Al-Bagieh, N.H. (1996). A study of the antimicrobial activity of the miswak ethanolic extract in vitro. Biomedical Letters, 53: 212-238.

Al-Shanti, H. (2003). Using Vitamin C and sodium bicarbonate to alleviate the effects of heat stress on rabbit performance. Egyptian Poultry Sci. J., 23: 129-139.

Amici, A. and Merendino, M. (1996). Some metabolic and immunological parameters in rabbits as affected by prolonged thermal stress. $6^{\text {th }}$ World Rabbit Congress, Toulouse, France, 2: 147-150.

AOAC, (2006). Association of Official Analytical Chemists. Official Methods of Analysis $18^{\text {th }}$ ed., Maryland, USA.

Ashour, G., Sedki, A.A. and El-Kholy, K.H. (2005). Efficiency of housing establishment for rabbits' productivity. In Proc.: $4^{\text {th }}$ Inter. Con. on Rabbit Prod. in Hot Clim., 24-27 Feb., 2005, Sharm El-Sheikh, Egypt, pp. 425434.

Ashour, G., Ibrahim, S.A., Ismail, A.M. and El-Kholy, K.H. (2004). Physiological reactions and biological performance of rabbits to summer heat stress. In Proc.: $2^{\text {nd }}$ Sci. Conf. Physio. Resp. Environ. Condi., 23-25 July, 2004, El-Arish, Egypt, pp. 165-186.

Ayyat, M.S. and Marai, I.F.M. (1996). Effects of summer heat stress on growth performance, some carcass traits and blood components of New Zealand White rabbits fed different dietary protein-energy levels under subtropical Egyptian conditions. $6^{\text {th }}$ World Rabbit congress, Toulouse, France, 2: 151-161.

Bahga, C.S., Preetinder, K. and Handa, M.C. (2010). Performance of meat and wool type rabbits as affected by heat stress and microclimatic modification. Indian J. Anim. Res., 44: 67-69.

Bani, P., Piccioli Cappelli, F., Minuti, A. and Abbatangelo, M. (2005). Variations of some blood parameters in rabbit reared under different environmental conditions. Ital. J. Anim. Sci., 4: 535-537.

Block, E. (1994). Manipulation of dietary cation-anion difference on nutritionally related production diseases, productivity and metabolic responses in dairy cows. J. Dairy Sci., 77: 1437-1450.

Bobyrev, V.N., Gaishenets, V.F. and Nikolov, O.T. (1988). Free radical oxidation of lipids in rabbits with nutritional peroxidation syndrome. Voprosy-Pitaniya, 5: 57-59 (Russian). 
Chew, B.P. (1995). Antioxidant vitamins affect food animal immunity and health. J. Nutr., 125: 1804-1808.

Daader, A.H., Gabr, H.A. and Seleem, T.S. (1999). Productive and reproductive performance of New Zealand White and Californian rabbit Bucks as affected by supplementing vitamin $A$ to the diet during summer and winter seasons. In Proc.: $7^{\text {th }}$ Conf. on Anim. Nutr. (Ruminants, Poultry and Fishes), 19-21 October, 1999, El-Arish, North-Sinai, Egypt, pp. 551 - 564 .

Drew, P., Harles, C.R.J.S., Trevor, B. and John, L. (2004). Oxford Handbook of Clinical Haematology, $2^{\text {th }}$ Edition, Oxford University Press, USA.

Duncan, D. B. (1955). Multiple range and multiple F. test. Biometrics, 11: 142.

El-Kholy, K.H., Hoda M.A. Shabaan, Gad-Alla, S.Z., Abdel-Kafy, E.M. and Mervat, N. Ghazal (2014). Productive and physiological responses of rabbit males to dietary organic chromium addition. Egyptian J. Rabbit Sci., 24: 1-18.

El-Kholy, K.H., Seleem, T.S.T, El-Aasar, T.A. and Hanaa Abdelharith (2008a). Effect of dietary addition of Arak (Salvadora persica) on growth and reproductive performance in Black Baladi rabbit males. World Rabbit Sci., 16: 21-27.

El-Kholy, K.H., El-Aasar, T.A., Hanaa Abdelharith and El-Damrawy, S.Z. (2008b). Some physiological and immunological responses of rabbits fed diets contained Salvadora persica. Egyptian J. Rabbit Sci., 18: 1529.

Fekete, S. and Gippert, T. (1986). Digestibility and nutritive value of nineteen important feedstuff for rabbits. J. Appl. Rabbit Res., 9: 103-108.

Feldman, B.F., Zinkl, J.G. and Jain, N.C. (2000). Schalm's Veterinary Hematology. Lippincott Williams and Wilkins, Philadelphia, USA.

Glue, T. and Hardy, J.D. (1970). Effect of pre-optic and spinal cord temperature in control of thermal polypnea. J. Appl. Physiol., 94: 540545.

Habeeb, A. A., El-Maghawry, A.M., Marai, I.F.M. and Gad, A. E. (1998). Physiological thermoregulation mechanism in rabbits drinking saline water under hot summer conditions. In Proc.: $1^{\text {st }}$ Inter. Conf. Anim. Prod. Health in Semi Arid Areas, 1-3 September, 1998, El Arish, North Sinai, Egypt, pp. 443-456.

Hattab, F.N. (1997). Muswak: the natural toothbrush. J. Clin. Dent., 8: 125129.

Henry, R.J., Canmon, D.C. and Winkelman, J.W. (1974). Principles and techniques, Harper and Row. Clin. Chem., pp. 415.

Hermes, I.H., Ahmed, B.M., Khalil, M.H., Salah, M.S. and Al-Homidan, A.A. (1999). Growth performance, nutrients utilization and carcass traits of growing Californian rabbits raised under different ambient temperatures. Egyptian J. Rabbit Sci., 9: 117-138.

Herz, A. and Shenhauf, D. (1985). The reaction of domestic animals to heat stress. Appl. Anim. Behaviour Sci., 14: 7-38. 
Ibrahim, S.A.M., Zanaty, G.A. and Abdel-Azim, A. (2005). Miswak and Khella as growth promoters in rabbits performance and some physiological aspects. Egyptian J. Poult. Sci., 25: 735-748.

Islam, M.W., Zakaria, M.N.M., Radhakrishnan, R., Liu, X.M., Chan K. and AlAttas, A. (2000). Anti-gastric ulcer and cytoprotective properties of Aarak tree (Salvadora persica) and Purslane (Portulaca oleracea) in rats. In Proc.: British Pharmaceutical Conf., Birmingham, England, pp. 301-308.

Jeon, S. M., Bok, S.H., Jang, M.K., Lee, M.K., Nam, K.T., Park, Y.B., Rhee, S.J. and Choi, M.S. (2001). Antioxidative activity of naringin and lovastatin in high cholesterol-fed rabbits. Life Sci., 2: 2855-2866.

Khodaei-Motlagh, M., Zare Shahneh, A., Masoumi, R. and Derensis, F. (2011). Alterations in reproductive hormones during heat stress in dairy cattle. Afric. J. Biotech., 10: 5552-5558.

Lee, C.Y. (2002). Explaining just how vitamin C works against cancer. The Lancet, 359: 9301-9305.

Lee, J.A., Roussel, J.D. and Beatty, J.F. (1976). Effect of temperature-season on bovine adrenal cortical function, blood cell profile and milk production. J. Dairy Sci., 59: 104-108.

Marai, I.F.M., Abd El-Monem, U.M. and Mahrose, Kh.M. (2008). Exotic male rabbit semen traits as affected by feeding systems and dietary supplementation with Nigella sativa seeds under Egyptian conditions. Egypt. Poult. Sci., 28: 833-847.

Marai, I.F.M., Ayyat, M.S. and Abd El-Monem, U.M. (2006). Growth performance, blood components and slaughter traits of New Zealand White male growing rabbits as affected by dietary supplementation with calcium, sodium or potassium, in subtropical Egypt. Trop. Subtropi. Agroecosys., 6: 149-155.

Marai, I.F.M., Habeeb, A.A.M. and Gad, A.E. (2002). Reproductive traits of male rabbits as affected by climatic conditions, in the subtropical environment of Egypt. Anim. Sci., 75: 451-458.

Marai, I.F.M., Ayyat, M.S. and Abd El-Monem, U.M. (2001). Growth performance and reproductive traits at first parity of New Zealand White female rabbits as affected by heat stress and its alleviation under Egyptian conditions. J. Trop. Anim. Health Prod., 33: 1-12.

Marai, I. F., El-Masry, K.A. and Nasr, A.S. (1994). Heat stress and its amelioration with nutritional, buffering, hormonal and physical techniques for New Zealand White rabbits maintained under hot summer conditions of Egypt. In Proc.: $1^{\text {st }}$ Int. Conf. Rabbit Prod. Hot Climates, 6-8 September, 1994, Cairo, Egypt, pp. 475-487.

McDowell, L.R. (2000). Vitamins in Animal and Human Nutrition. lowa State Press, lowa, USA.

Morsy, W.A., Hassan, R.A. and Abd El-Lateif, A.I. (2012). Effect of dietary ascorbic acid and betaine supplementation on productivity of rabbit does under high ambient temperature. In Proc.: 10 ${ }^{\text {th }}$ World Rabbit Congress, 3-6 September, 2012, Sharm El- Sheikh, Egypt, pp. 279 283 
Möstl, E. and Palme, R. (2002). Hormones as indicators of stress. Domestic Animal Endocrinol., 23: 67-74

NRC (1977). National Research Council: Nutrient Requirements of Rabbits. $2^{\text {nd }}$ Revised Edition, National Academy of Sciences, Washington, DC. USA.

Nowaczewski, S. and Kontecka, H. (2012). Haematological indices, size of erythrocytes and haemoglobin saturation in broiler chickens kept in commercial conditions. Anim. Sci. Pap. Rep., 30: 181-190

Lebas, F., Coudert, P., Rochambeau, H. De. and Thébault, R.G. (1997). The rabbit husbandry, health and production. Food and Agriculture Organization of the United Nations, FAO, Rome, Italy.

Ogunjimi, L.A.O., Ogunwande, G.A. and Osunade, J.A. (2008). Rabbit weight gain, feed efficiency, rectal temperature and respiration rate as affected by building thermal environment in the humid tropical climate of Southwestern Nigeria. Agric. Engine. Inter., 10: 1-14.

Okab, A. B., El-Banna, S.G. and Koriem, A. A. (2008). Influence of environmental temperatures on some physiological and biochemical parameters of New-Zealand rabbit males. Slovak J. Anim. Sci., 41: 1219.

Ondruska, L., Rafay, J., Okab, A.B., Ayoub, M.A., Al-Haidary, A.A., Samara, E.M., Parkanyi, V., Chrastinova1, L., Jurcik1, R., Massanyi, P., Lukac, N. and Supuka, P. (2011). Influence of elevated ambient temperature upon some physiological measurements of New Zealand White rabbits. Vet. Med., 56: 180-186.

Rafai, P. and Papp, Z. (1984). Temperature requirement of rabbit does for optimal performance. Archiv Fur Exprimntalle Veterinarmedizin, 38: 450-457.

SPSS (2012). SPSS User's Guide Statistics Version 19. Copyright IBM, SPSS Inc., USA.

Sunmonu, T.O. and Oloyede, O.B. (2007). Biochemical assessment of the effects of crude oil contaminated catfish (Clarias gariepinus) on the hepatocytes and performance of rat. Afric. J. Biochem. Res., 1: 83-89.

Suttle, N.F. (2010). The mineral nutrition of livestock. $4^{\text {th }}$ Edition, CAB International Publishing, UK.

Warren, J.E. and Gregory, G. (2005). Statistical Methods in Bioinformatics: An Introduction (Statistics for Biology and Health). Springer Science press, New York, USA.

White, L.A., Newman, M.C., Cromwell, G.L. and Lindemann, M.D. (2002). Brewers dried yeast as a source of mannan oligosaccharides for weanling pigs. J. Anim. Sci., 80: 2619-2628.

Wittorf, E.K., Heird, C.E., Rakes, J.M. and Johnson, Z.B. (1988). Growth and reproduction of nutrient restricted rabbits in a heat stressed environment. J. Appl. Rabbit Res., 11: 87-92.

Yousef, M.I., Kamel, K.I., Esmail, A.M. and Baghdadi, H.H. (2004). Antioxidant activities and lipid lowering effects of isoflavone in male rabbits. Food Chem. Toxicol., 42: 1497-503. 
Zeferino, C. P., Komiyama, C. M., Fernandes, S., Sartori, J. R., Teixeira, P. S. S. and Moura, A. S. A. M. T. (2013). Carcass and meat quality traits of rabbits under heat stress. Anim., 7: 518-523.

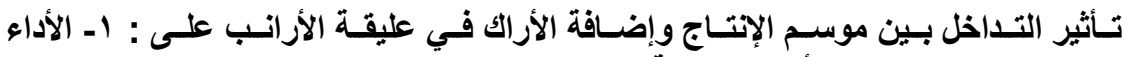
الإنتاجي والفسيولوجي للأرانب النامية الإنية

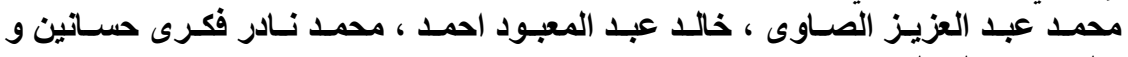
خالد حسان الخولي التئي

قسم بحوث تربية الأرانب والرومي والطيور المائية، معهل بحوث الإنتاج الحيواني، مركز البحوث الزراعية، الاقي - جيزة - مصر الانب والرودي

تهدف هذه الدارسة إلى تقييم تأثير موسم الإنتاج و الإضـافة الغذائية لمسحوق نبات الأراك و التداخل

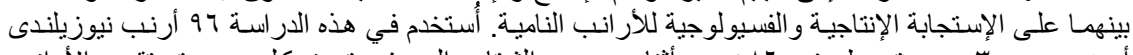

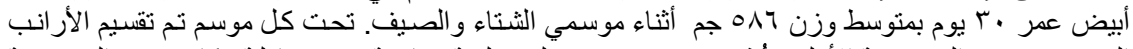

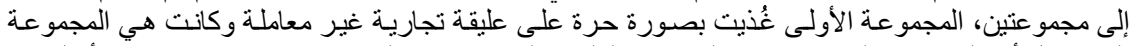

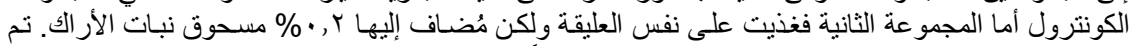

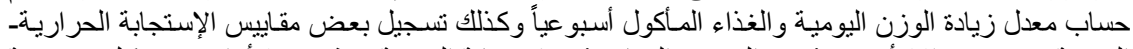

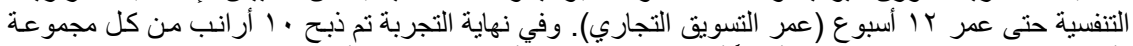

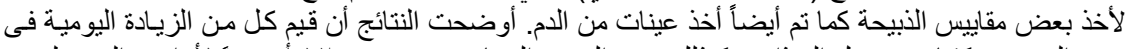

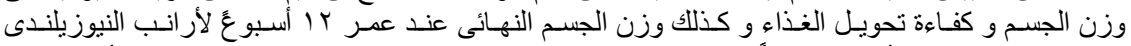

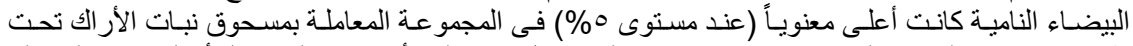

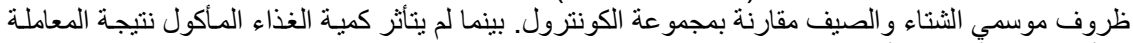

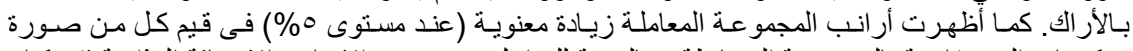

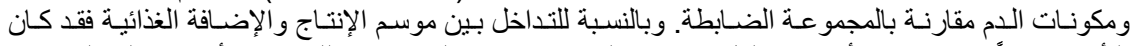

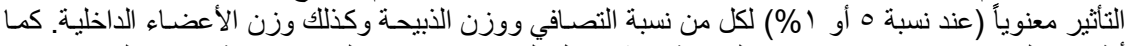

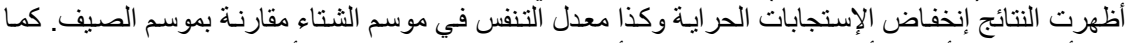

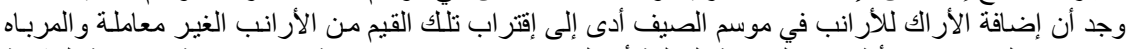

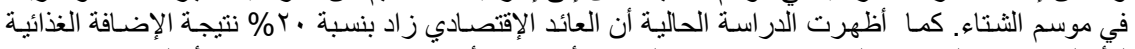

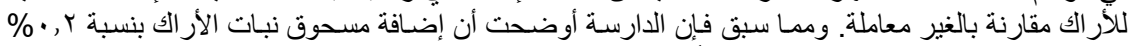

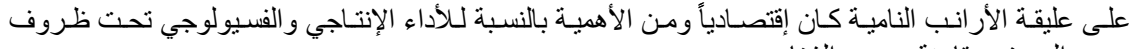
موسم الصيف مقارنة بموسم الثنتاء. 
Table 6: Effect of season, Arak treatment and their interactions on dressing percentage and internal organs weight of growing NZW rabbits.

\begin{tabular}{|c|c|c|c|c|c|c|c|c|}
\hline Traits & $\begin{array}{l}\text { Pre-slaughter } \\
\text { body weight } \\
\text { (g) }\end{array}$ & $\begin{array}{l}\text { Carcass } \\
\text { weight } \\
\text { (g) }\end{array}$ & $\begin{array}{c}\text { Dressing } \\
\text { percentage } \\
(\%)\end{array}$ & $\begin{array}{l}\text { Relative Head } \\
\text { weight } \\
(\%)\end{array}$ & $\begin{array}{c}\text { Relative } \\
\text { kidneys } \\
\text { weight (\%) }\end{array}$ & $\begin{array}{c}\text { Relative liver } \\
\text { weight } \\
(\%)\end{array}$ & $\begin{array}{l}\text { Relative heart } \\
\text { and lungs } \\
\text { weight (\%) }\end{array}$ & $\begin{array}{c}\text { Relative hind } \\
\text { part weight } \\
(\%)\end{array}$ \\
\hline Season: & ** & ** & ** & * & * & * & * & $\star \star$ \\
\hline Winter (W) & $1563.25 \pm 13.70^{a} 1$ & $1084.40 \pm 9.16^{a}$ & $69.25 \pm 0.631^{\mathrm{a}}$ & $6.62 \pm 0.12^{b}$ & $0.74 \pm 0.007^{\mathrm{a}}$ & $2.72 \pm 0.025^{\mathrm{a}}$ & $0.43 \pm 0.004^{a}$ & $25.11 \pm 0.42^{\mathrm{a}}$ \\
\hline Summer (S) & $1279.05 \pm 13.70^{b}$ & $801.65 \pm 9.16^{b}$ & $62.50 \pm 0.631^{b}$ & $7.23 \pm 0.12^{\mathrm{a}}$ & $0.69 \pm 0.007^{b}$ & $2.40 \pm 0.025^{b}$ & $0.42 \pm 0.004^{b}$ & $23.45 \pm 0.42^{b}$ \\
\hline Treatment: & $* *$ & $* *$ & $* *$ & * & * & * & * & $* *$ \\
\hline Control (C) & $1327.10 \pm 13.70^{b}$ & $854.35 \pm 9.16^{b}$ & $63.95 \pm 0.63^{b}$ & $6.47 \pm 0.12^{\mathrm{a}}$ & $0.70 \pm 0.007^{b}$ & $2.42 \pm 0.025^{b}$ & $0.42 \pm 0.004^{b}$ & $22.76 \pm 0.42^{b}$ \\
\hline Treated $(\mathrm{T})$ & $1515.20 \pm 13.70^{\mathrm{a}}$ & $1031.70 \pm 9.16^{a}$ & $67.80 \pm 0.63^{\mathrm{a}}$ & $6.11 \pm 0.12^{b}$ & $0.73 \pm 0.007^{\mathrm{a}}$ & $2.70 \pm 0.025^{\mathrm{a}}$ & $0.43 \pm 0.004^{a}$ & $26.46 \pm 0.42^{a}$ \\
\hline Interactions: & $* *$ & ** & $* *$ & $* *$ & * & * & * & $* *$ \\
\hline$W \times C$ & $1475.3 \pm 19.38^{\mathrm{b}}$ & $997.50 \pm 12.96^{b}$ & $67.60 \pm 0.89^{b}$ & $6.42 \pm 0.13^{b}$ & $0.71 \pm 0.009^{b}$ & $2.52 \pm 0.035^{b}$ & $0.42 \pm 0.006^{b}$ & $25.91 \pm 0.42^{b}$ \\
\hline$S \times C$ & $1178.90 \pm 19.38^{d}$ & $711.20 \pm 12.96^{d}$ & $60.30 \pm 0.89^{d}$ & $7.48 \pm 0.13^{a}$ & $0.68 \pm 0.009^{c}$ & $2.31 \pm 0.035^{c}$ & $0.40 \pm 0.006^{c}$ & $22.23 \pm 0.42^{\mathrm{d}}$ \\
\hline$W \times T$ & $1551.20 \pm 19.38^{\mathrm{a}} 1$ & $1081.30 \pm 12.96^{a}$ & $68.90 \pm 0.89^{\mathrm{a}}$ & $6.12 \pm 0.13^{d}$ & $0.76 \pm 0.009^{a}$ & $2.61 \pm 0.035^{\mathrm{a}}$ & $0.44 \pm 0.006^{a}$ & $26.75 \pm 0.42^{a}$ \\
\hline$S \times T$ & $1379.20 \pm 19.38^{c}$ & $892.10 \pm 12.96^{c}$ & $64.70 \pm 0.89^{c}$ & $6.24 \pm 0.13^{C}$ & $0.70 \pm 0.009^{b}$ & $2.48 \pm 0.035^{d}$ & $0.41 \pm 0.006^{b}$ & $24.13 \pm 0.42^{c}$ \\
\hline
\end{tabular}

$*=\mathrm{P} \leq 0.05 ; * *=\mathrm{P} \leq 0.01$

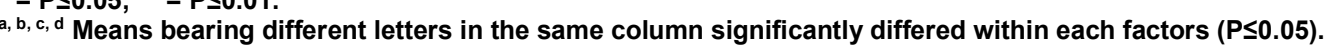

